\title{
Quantitative Estimation of Recharge Potentialities of Shallow Aquifers in Senegal River Delta Hydrosystem
}

\author{
Moctar Diaw ${ }^{1,2, ~ *, ~ I b r a h i m a ~ M a l l ~}{ }^{1}$, Marc Le Blanc ${ }^{2}$, Serigne Faye ${ }^{1}$, Yves Travi ${ }^{2}$ \\ ${ }^{1}$ Department of Geology, Faculty of Sciences and Technique, Cheikh Anta DIOP University, Dakar, Senegal \\ ${ }^{2}$ Faculty of Sciences, University of Avignon, Avignon, France
}

\section{Email address:}

mkdiaw@yahoo.fr (M. Diaw), moctar.diaw@ucad.edu.sn (M. Diaw)

${ }^{*}$ Corresponding author

\section{To cite this article:}

Moctar Diaw, Ibrahima Mall, Marc Le Blanc, Serigne Faye, Yves Travi. Quantitative Estimation of Recharge Potentialities of Shallow Aquifers in Senegal River Delta Hydrosystem. American Journal of Water Science and Engineering. Vol. 5, No. 2, 2019 , pp. 47-61. doi: 10.11648/j.ajwse.20190502.12

Received: April 2, 2019; Accepted: May 23, 2019; Published: June 26, 2019

\begin{abstract}
The objective of this paper is to assess quantitatively the potential recharge of shallow aquifers in the Senegal River delta in context of semi-arid climate, of massive irrigation development and of modification of hydrologic and hydrogeological characters after dams building. Quantitative estimation of recharge potentialities have been based on hydrological balance and groundwater table fluctuation calculations and on isotopic tracers techniques of the water molecule $\left(\delta^{18} \mathrm{O}, \delta^{2} \mathrm{H}\right.$ and $\left.{ }^{3} \mathrm{H}\right)$. This different methodological approaches used to estimate recharge rates have been useful, valuable and complementary. They give results fairly homogeneous and very interesting with indications accurate enough on recharge rates and on recharge spatio-temporal variations in shallow aquifers in alluvial plain (rate varying between $0-37 \%$ of annual rainfall) and dunes formations (rate varying between $0-44 \%$ of annual rainfall). Results indicate that recharge variations in term of proportions and of distribution are not only depending of volume and frequency rainfall or groundwater depth but also depending of soil and subsoil surface conditions, human activities (water withdraw, irrigation, market gardening, etc.) and evaporative demand. This recharge knowledge in terms of proportions and distribution in shallow aquifers is often very useful to propose groundwater resources management model and to define strategies to exploit them sustainably especially when groundwater resources are very unproductive and often very salty as in Senegal River delta.
\end{abstract}

Keywords: Recharge Rate, Hydrological Balance, Groundwater Fluctuation, Isotopic Tracers, Shallow Aquifers, Senegal River Delta Hydrosystem

\section{Introduction}

The Sustainable management of groundwater resources to meet human and ecosystem needs would require a more accurate recharge estimate under varying land use/cover conditions in different periods. The recharge is the parameter that is usually the least well known, and the most important for hydrogeological resources quantification, especially in semi-arid environments where recharge processes are heterogeneous and variable in space and time [1-3]. This heterogeneity is related to the high variability of hydroclimatological parameters (rainfall, runoff and infiltration) which increases with aridity [4] and hydraulic characteristics of aquifers. Knowledge of the groundwater origin and its renewal rate is essential in the management of shallow aquifers in semi-arid zone especially when they are in hyper-salty fluvio-deltaic environments, at which the irrigation practice is almost permanent. This is all the more problematic in the delta, as the volumes of water consumed and reinjected into the environment have increased considerably in recent decades to meet agricultural needs, further increasing the sensitivity and fragility of groundwater resources and soils. Therefore, estimating recharge under these conditions is essential when groundwater resources are increasingly exposed to climate changes effects and environmental conditions, as is the case of Senegal River delta. Estimating recharge, in these environments types, is therefore to evaluate in a relevant way: what is known and what is measurable. For groundwater recharge quantification, 
a wide variety of methods have been proposed [5-8]. But the choice of appropriate methods for a particular site is often difficult and is not automatic. Indeed, it depends on sources, mechanisms and on factors: such as time and space scales, the range of values and the validity (accuracy and reliability) of the estimates rates [9]. In arid and semi-arid regions, extreme variability in recharge can be observed, related to direct infiltrations, preferential flows in certain soil structures (earthworm holes, termite mounds and root tracks) as well as only localized percolations at topographic depressions and rivers, in irrigated fields and in sewage disposal areas [10]. On the whole, and according to the specificity of the Senegal River delta, many estimating methods of recharge have been reviewed. In particular techniques estimation of potential recharge based on climate, hydrology and unsaturated zone data and techniques estimation of actual recharge based on physical, chemical and isotopic groundwater data [9]. The objective of this study is to assess recharge in terms proportion and distribution from measurements of water table fluctuations, the hydrological balance calculation and using stable $\left(\delta^{18} \mathrm{O}\right.$ and $\left.\delta^{2} \mathrm{H}\right)$ and radiogenic $\left({ }^{3} \mathrm{H}\right.$, tritium) isotopic tracers of the water molecule. The choice of this methods has been based on the simplicity of their principles, on the accuracy of the input data and on the validity of their results through the site.

\section{Theoretical Background}

Most of groundwater recharge studies in Africa have often been carried out on a small scale on a parcellar basis in order to define the local fundamentals of recharge aspects, such as source, scale, magnitude and distribution. The knowledges details on recharge studies in Africa, of which the majority relate to arid and semi-arid environments and their equivalents around the world were presented [3]. These authors proposed a global synthesis of the results of 140 studies on recharge in arid and semi-arid regions (including Africa) and provided important information on rates, mechanisms and processes of recharge. According to these authors, average rates of recharge vary between 0.2 and 35 $\mathrm{mm} /$ year corresponding to $0.1-5 \%$ of the annual average rainfall. They indicate transient aspects such as the frequency of recharge events and the transit time leading to actual recharge are important to be considerate. Thus, recharge processes that are designed more easily, form the basis of many techniques for estimating recharge in currently use. The first and most obvious approach to assessing infiltration or recharge problems should be the study of transfer of water or percolation fluxes through the unsaturated zone. But, as noted [11-13], the complexity of this zone has not yet made it easy and routine to use certain applied methods. It is therefore natural that hydrogeologists have based on other methods and techniques for evaluating recharge, whose the most frequently used are: direct measurements of groundwater level fluctuations related to precipitation, hydroclimatological balances assessments at different scales (local or regional watershed) or calculation of water balance based on soil, climate and vegetation data, hydrogeological models, physical approaches related to vertical flow measurements in unsaturated zone or direct calculation of the water flow, applying natural (isotopic or chemical) and artificial tracers techniques, mathematical and empirical methods etc. Most of the principles and problems encountered on methods are discussed [12, 7, 14-17], among others. The summary of comparisons between different methods have been proposed [7, 18-19]. They have indicate that most of these used methods have not provided good precisions in arid and semiarid zones. Thus, studies [3, 10], have described and proposed, principles of different techniques of recharge estimation most adapted in arid or semi-arid regions. They indicate that recharge estimation techniques which are applicate, highly varies. Important elements for choosing appropriate techniques are the time and space scale, and the validity of recharge values [9]. This recharge values estimated must be adapted to expected recharge values on the site. It why recharge processes need to be understood or conceptualized and the flow system and its main modes can be defined to appropriate assessment methods of recharge could be used taking into account uncertainties in time and space [20]. Considering the recharge estimation process is iterative, it is indicate to apply and compare multiple independent approaches because of associated uncertainties on each approach and to increase the validity of recharge estimates. What was done in the Senegal River delta?

\section{Materials and Methods}

\subsection{Site Description}

The geographical setting comprises the delta and the lower valley of the Senegal River; it lies between longitudes $15^{\circ} 400$ and $16^{\circ} 350 \mathrm{~W}$ and latitudes $15^{\circ} 450$ and $16^{\circ} 350 \mathrm{~N}$. The SRLVD is limited to north by the Senegal River, in the west by the Atlantic Ocean, the east by the Ferlo (dried region) and in the south by the latitude $16^{\circ} 400$ (Figure 1); the surface area is about $6,000 \mathrm{~km}^{2}$. The region lies in the semiarid to arid Sahelian band characterized by a coastal climate with mean temperature around $27^{\circ} \mathrm{C}$ (with minimum between $22^{\circ} \mathrm{C}$ and $24^{\circ} \mathrm{C}$ and maximum between $35^{\circ} \mathrm{C}$ and $37^{\circ} \mathrm{C}$ ), potential evapotranspiration between 2,000 and $2,500 \mathrm{~mm}$ and precipitation between 200 and $400 \mathrm{~mm}$. The Senegal River, with headlands located south in the Fouta Djalon Mountains of Guinea and in Mali (where precipitation of more than 2,000 mm/year is recorded), is $1,760 \mathrm{~km}$ long and flows through the western part of Mali, then along the Mauritania-Senegal frontier before reaching the delta and the ocean. The river flow regime is unimodal and strongly influenced by seasonal rain; peak flows are recorded from August to November. In the lower valley and delta regions, the river discharges during high-water stage in many hydrological systems comprising streams, depressions and lakes (Guiers Lake fed through a regulated channel). With these transfers, river water overflowing flood annually alluvial plain characterized by low topography and clay soil 
(Figure 1). Since the mid-1980s, the river flow regime has been regulated by two dams (Manantali in Mali, Diama located $27 \mathrm{~km}$ upstream of Saint-Louis). The Diama Dam was designed to prevent the intrusion of ocean water and also to feed the reservoir used for irrigation and human needs. Since 1992, the management plan application of the Senegal river water level, (between 1.50 and $2.50 \mathrm{~m}$ National
Geographic Institute), have change the river hydrological regime marked by the passage of a transient flow regime of seasonal intertropical type to a quasi-permanent flow regime. Actually, with improved control of water resources and technology, irrigated agriculture has experienced rapid expansion and constitute currently the driving force for socio-economic development in the area.

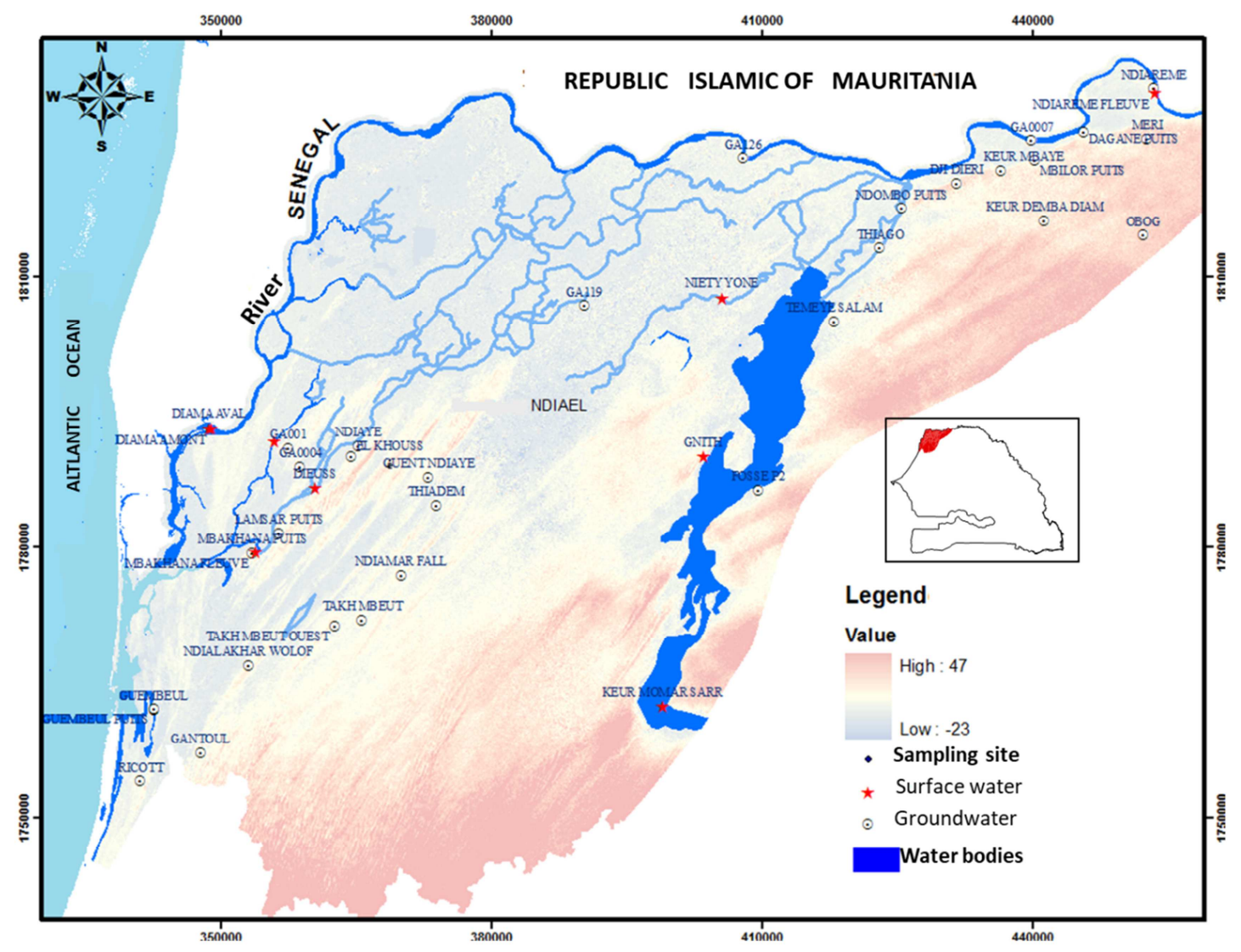

Figure 1. Location and sampling water site map.

\subsection{Geological and Hydrogeological Settings}

The subsurface sediments are originally marine and complex; they are composed of quartz, halite, montmorillonite, kaolinite, illite, gypsum, calcite as fossils (gastropods, lamellibranches), pyrite and ferruginous minerals resulting from the influence of the hydroclimatological factors of the fluvial deltaic lagoon and continental media. The geomorphology of the area derived from both erosion and depositional sequences was used by [21], to differentiate aquifers present in the system (Figure 2):

The ancient ergs (vast NNE-SSW longitudinal dunes) edified during the ogolian period, a period of strong marine regression $(-100 \mathrm{~m})$ and extreme aridity. The sediments are composed of isometric sand grain $(0.2 \mathrm{~mm})$ often coated with ferruginous clay. The whole system overlies an Inchirian semi-permeable sandy clay layer, which is generally used as limit between the freshwater in the sand dunes aquifer and saline water in the Inchirian aquifer. The recent ergs (marine terraces) induced by the Nouakchottian transgression [22], are composed of fine, white and isometric sand grains bearing some Anadara senilis shells and gravels overlaying argillaceous sand sediments. These are very characteristic in the lower valley zone and constitute the transition zone between the ancient erg and the flood plain. Thus, in the deltaic zone, the Ogolian and the Nouakchottian aquifer formations appear in the form of freshwater lenses with limited extension, whereas toward the south and the east of the Guiers Lake, where marine facies reach their extreme extension, the aquifer composed of ogolian red sands can bear important freshwater resources with thickness greater than $6 \mathrm{~m}$. Following the Nouakchottian transgression, the delta was transformed into complex lagoons in the form of elongated golf evolving via an endorheic mode. In the east part of the golf, the alluvial sediments dominate lagoon sedimentation and limit the expansion of the mangroves in the delta. These sediments, which are composed of fine sands, clays and compacted yellow silts, incorporate sulfate acid and salt crusts. In low altitude zone, the muddy clay sediments are marked by a higher salinity related to the successive marine invasions and the absence of drainage in 
the depression ground surface [23]. This alluvial aquifer is fed by flooded water in the inundation plain. Transmissivity and hydraulic conductivity values are variable and they range from $10^{-2}$ to $4.8910^{-6} \mathrm{~m}^{2} / \mathrm{s}$ and from $0.4910^{-4}$ to $6910^{-5} \mathrm{~m} / \mathrm{s}$, respectively. Groundwater table is shallow in the flood plain zone $(1.6-6 \mathrm{~m})$ and reach to $20 \mathrm{~m}$ depth in the sand dunes area [24]. For this system, due to the limited number of monitoring wells, a piezometric map could not be established. The few measured head values indicate flow direction mainly from the river toward inland for both seasons (high-water and low-water stages). In the sand dunes area, irregular head variability occurred, which could be attributed to the slow and diffuse infiltration process [25].

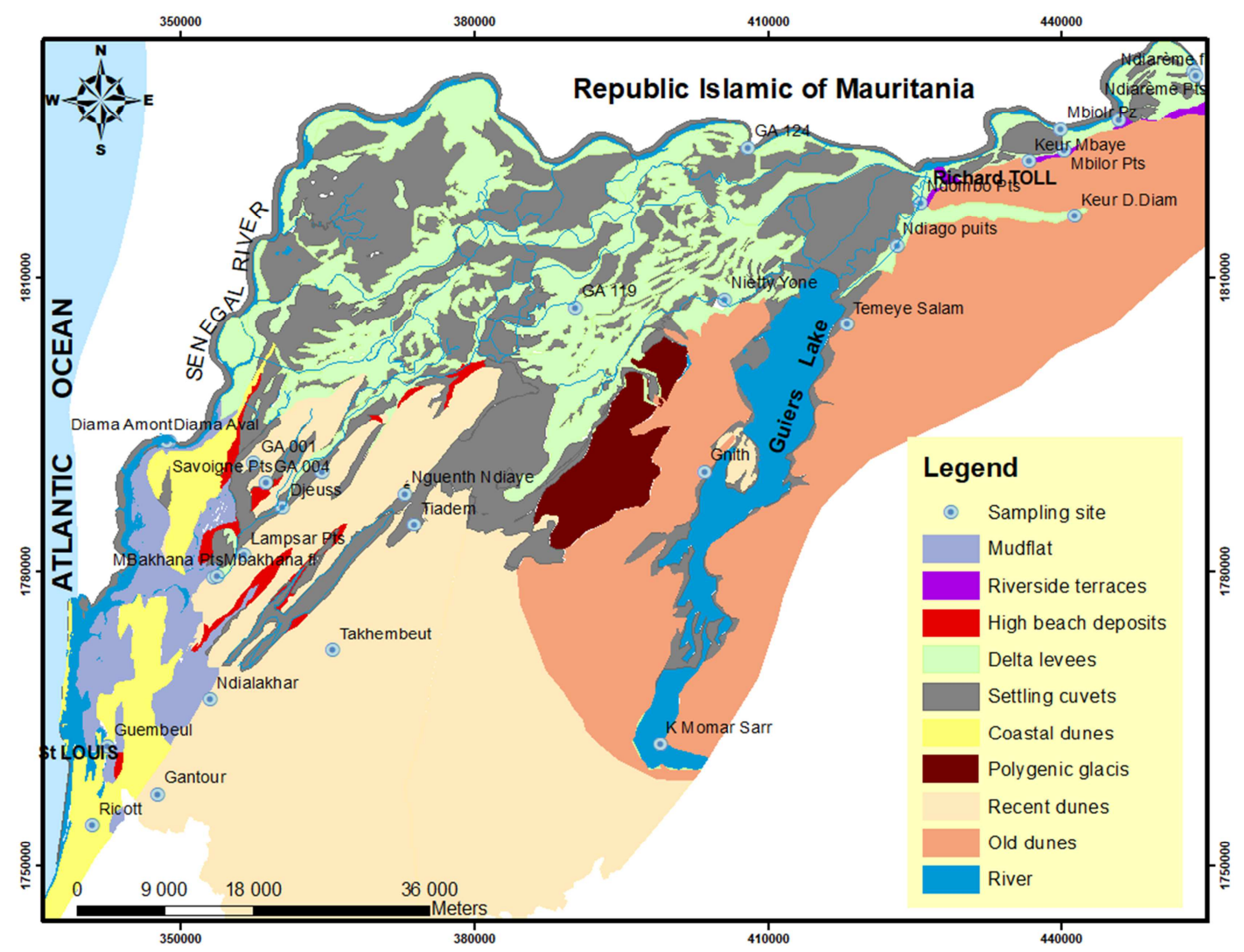

Figure 2. Geology and geomorphological [26].

\subsection{Data Acquisition, Sampling, Field Works and Analytical Procedure}

Climatical data series (Temperature, rainfall, atmospheric pressions, evaporation, etc.) were compiled by National Agency of Civil Aviation and Meteorology (NACAM) data base. Saint-Louis and Dagana stations located respectively in the south-west and in the north-east part of the zone, were chosen on the basis of their positioning and the existence of diachronic series of complete data without major interruption (1986-2016). The sampling campaigns were conducted in July 2005 (dry season) and December 2013 (end of rainy season) for the Senegal River delta system. The sampling campaigns include groundwater collected from the alluvial plain and dunes formation occurring a network of 24 points and surface water collected from three sites in the Guiers Lake and at five sites along the Senegal River course. The locations of the sampling points are shown in Figure 1. Prior to sampling, depths of water table were recorded for each site. For piezometric variations monitoring, twenty-four points were selected on the basis of complete and regular data series. The choice of these points, especially in the alluvial plain was also guided by their location in relation to irrigation schemes, hydraulics axis itself and groundwater level collected (upper compartment of shallow aquifer). The monthly monitoring data of water table fluctuation used (between 2011 and 2013) were taken from piezometers equipped DIVER-type continuous recorders belonging to SAED monitoring network. Hydrogen and oxygen isotopes analysis were performed at the IAEA (International Atomic Energy Agency) and at the hydrogeology laboratory of Avignon University by, respectively, employing the standard $\mathrm{CO}_{2}$ equilibration [27] and the zinc reduction techniques [27], followed by measurement by isotope ratio mass spectrometer FINNIGAN MAT type DELTA S. All oxygen and hydrogen isotopes analyses are expressed in the conventional d-per mil (d-\%o) notation referenced from the Vienna-Standard Mean Oceanic Water (V-SMOW). The analytical reproducibility is $\pm 0.1 \%$ for oxygen and $\pm 1.0 \%$ for deuterium, respectively. Tritium analyses were performed by electrolytic enrichment and analyzed with a liquid scintillation counting method [29]. The results are reported as tritium unit (TU) with a typical error of $\pm 0.7 \mathrm{TU}$. 


\section{Results and Discussions}

\subsection{Recharge Estimation from Hydrological Balance Methods}

Methods for estimating recharge through water balance, based on the law of mass conservation in the hydrological cycle, generally provide a regional estimate of recharge. They are most often subject to errors or uncertainties related to the high spatial and temporal variability of hydrological events, to the reliability of climatological data (evapotranspiration, precipitation, etc.) and to the simplifying assumptions of methods used. In semi-arid environments as in Senegal River delta, the annual water budget estimate is not always easy to apply because of the small recharge rate calculated from the difference between precipitations $(\mathrm{P})$ and Potential EvapoTranspiration (PET). On annual scale, PET is much greater than rainfall and recharge is sporadic and restricted to the rainy season or to the flooding period of irrigated land. Added to this are local variability related to topography, soil types, vegetation, geology, and land use [5, 29]. We have therefore proposed in this paper, two methodological approaches to evaluate recharge proportions from the water balance. This is the estimation method of the PET developed by [31] and that developed at the University of Liège and called "Water budget". The application of these hydrological balance methods was made specifically for years 2005, 2011, 2012 and 2013, in order to be able to compare them with results from water table fluctuation calculations and isotope tracing methods which also considered these years of measurements.

\subsubsection{Camus and Debuisson Method}

In this method, mean values of monthly PET $\left(\mathrm{PET}_{\mathrm{m}}\right)$ were calculated taking into account values of Piches evaporation measured in the area (Ev) multiplied by a corrective factor $\mathrm{C}$ equal to $0.6 * 0.74$ specific to the sub-Saharan zone [31]. The effective precipitation $\left(\mathrm{P}_{\text {eff }}\right)$ which correspond to infiltration and runoff, is calculated taking into account the Precipitation (P), the Potential EvapoTranspiration (PET) which indicates the effective value of the evaporation in the soil moisture conditions of the region and the Useful Easily Reserve (UER). The hydrological balance is given by:
$\mathrm{P}($ Precipitation $)=$ PET + Run off + Infiltration + UER (1)

Or $\mathrm{P}_{\text {eff }}=$ Run off + Infiltration $=\mathrm{P}-\mathrm{PET}-\mathrm{UER}$

The UER is defined as the amount of water that can be mobilized by evapotranspiration; it is often considered by default to be equal to $100 \mathrm{~mm}$ in the Sahelian zones for calculating the water balance. This parameter has two limitations. The upper limit represents the maximum amount of water that the soil can retain by capillarity. As for the lower limit, it corresponds to under conditions which the wilting point of plants is reached. Thus, root suction forces are insufficient for the extraction of water contained in the soil. When the effect of drought is very severe, plants are under water stress and their transpiration activity decreases. Thus, the easily usable soil reserve (EUSR) of the vegetation cover is defined. This EUSR varies with soils type and is roughly half of the UER [32]. Thus,

$$
\text { Peff }=\text { P- PET }- \text { EUSR }
$$

With PET $=\mathrm{E}_{\mathrm{V}} * 0.6 * 0.74$ and $\mathrm{P}_{\mathrm{eff}}=\mathrm{P}-\left(\mathrm{EV}^{*} 0.6 * 0.74\right)-$ EUSR.

Overall, the $\mathrm{P}_{\text {eff }}$ can represent, according to years of measurements, between 0 and $43 \%$ and 2 and $22 \%$ of precipitation respectively in Saint-Louis and Dagana stations (Table 1). These values represent the annual rainfall part that contributes to both surface runoff and shallow groundwater recharge, highly depend on hydroclimatical factors, particularly precipitated water volumes and their frequency over time. In sandy dunes formations and sand-silty-clay deposits of the alluvial plain (semi-confined aquifer localized in the northeast), we can consider that surface runoff is nil or negligible. Thus, in these contexts the part of $\mathrm{P}_{\text {eff }}$ can be likened to the infiltration part or recharge $\left(\mathrm{P}_{\text {eff }}=\right.$ Infiltration= Recharge). Recharge values estimated by [31] method, in dunes formations and alluvial plain varies between 2 and $22 \%$ of precipitation towards Dagana station. Contrariwise, in downstream of the alluvial plain characterized by clay-silt deposits more conducive to runoff, average infiltration values are lower. They can theoretically correspond to half of the $\mathrm{P}_{\text {eff }}\left(\right.$ Recharge $\left.=1 / 2 \mathrm{P}_{\text {eff }}\right)$ which can represent between $0-22 \%$ of annual precipitation. Therefore, in dunes formations near to Saint-Louis station, recharge values can reach to $43 \%$ of annual precipitation (Table 1).

Table 1. Hydrological balance estimated from Camus and Debuisson method in Saint Louis and Dagana stations.

\begin{tabular}{lllllllll}
\hline Stations & Dagana & \multicolumn{7}{c}{ Saint Louis } \\
\hline years & $\mathbf{2 0 0 5}$ & $\mathbf{2 0 1 1}$ & $\mathbf{2 0 1 2}$ & $\mathbf{2 0 1 3}$ & $\mathbf{2 0 0 5}$ & $\mathbf{2 0 1 1}$ & $\mathbf{2 0 1 2}$ & $\mathbf{2 0 1 3}$ \\
\hline Precipitation $(\mathrm{mm})$ & 261,6 & 276,8 & 386,8 & 374,5 & 261,5 & 167,6 & 322,4 & 375,2 \\
PET $(\mathrm{mm})$ & 1298,5 & 1388,6 & 1408,6 & 1596,4 & 1124 & 1242 & 1398 & 1441,4 \\
P-PET (mm) & -1017 & $-1111,8$ & $-1021,8$ & $-1221,6$ & $-862,5$ & $-1074,4$ & $-1075,6$ & $-1066,2$ \\
UER (mm) & 597 & 620,7 & 545,5 & 311,2 & 412,9 & 254,4 & 368,9 & 355,7 \\
RET $(\mathrm{mm})$ & 170,1 & 145,4 & 136,4 & 291,4 & 189,0 & 152,1 & 220,8 & 207,8 \\
P eff $(\mathrm{mm})$ & 29,7 & 31,4 & 113,1 & 83,7 & 72,5 & 15,4 & 101,5 & 167 \\
P eff $(\%)$ & $2-22 \%$ & & & & 0 et $44 \%$ & & & \\
\hline
\end{tabular}

*P: Precipitation, PET: Potential EvapoTranspiration, UER: Used Easily Reserves, RET: Real Evapotranspiration, Peff: efficient Precipitation.

\subsection{2. "Water Budget" Method}

For the " Water budget " method developed at the
University of Liège, the average monthly PET values ( $\left.\mathrm{PET}_{\mathrm{m}}\right)$ were calculated from the THORNWAITE formula [33] 
which takes into account average monthly temperatures $\left(\mathrm{T}_{\mathrm{m}}\right)$, the annual thermal index (I) and a corrective factor $\mathrm{K}$ which is function of the month $(\mathrm{m})$ and latitude:

$$
\begin{gathered}
\text { PETmonth }=16\left(\frac{10 T m}{I}\right) * K \\
\mathrm{I}=\sum_{m=1}^{12}\left(\frac{\mathrm{Tm}^{1,514}}{5}\right)
\end{gathered}
$$

With $\mathrm{a}=6.75 * 10^{-7} \mathrm{I}^{3}-7.71 * 10^{-5} \mathrm{I}^{2}+1.79 * 10^{-2} \mathrm{I}+49$ or $\mathrm{a}$ $\approx 0,016 \times \mathrm{I}+0.5$ (approached formula).

It is from the $\mathrm{PET}_{\mathrm{m}}$ calculated that the AET and effective stock representing runoff and infiltration are estimated by the model with:

$$
\text { Stockeff } \approx \text { Peff }=\mathrm{R}+\mathrm{I}=\mathrm{P}-\mathrm{ETR}
$$

If we consider, all years of measurements, Stock $_{\text {eff }}$ in the zone, varies respectively between $4-26 \%$ and $0-18 \%$ of annual precipitation in Saint-Louis and Dagana stations (Table 2). On the basis of the same principle linking $\mathrm{P}_{\text {eff }}$ and recharge, we can estimate in the dunes and in the sandy-silty deposits of the alluvial plain north-east upstream (semiconfined aquifer), average recharge proportions varying between $0-18 \%$ of annual precipitation. These proportions can reach $26 \%$ in southwestern dunes near to Saint-Louis station while in the alluvial plain, recharge proportions are estimated between $2-14 \%$ of annual precipitation. These results correspond within average ranges values found by the previous method (Table 1). However, few variations observed in the results could be associated with formulations and hypotheses, but also with the various climatic parameters considered in calculations used. Considering, results of two methods, we noticed that the water budget remains overall deficit or nil. The only periods favorable to shallow aquifers recharges coincide with the rainy season (August, September and exceptionally during the months of July and October according to the specificity of the hydrological year). These recharge values in this area, are very dependent on rainfall volume and frequency, soil and subsoil surface conditions

\begin{tabular}{|c|c|c|c|c|}
\hline \multirow{2}{*}{ Stations } & \multicolumn{4}{|l|}{ years } \\
\hline & 2005 & 2011 & 2012 & 2013 \\
\hline Saint Louis Stock eff/ APr (\%) & $21 \%$ & $4,6 \%$ & $14,3 \%$ & $26,5 \%$ \\
\hline Dagana Stock eff/ APr (\%) & $15,7 \%$ & $18,2 \%$ & $0 \%$ & $18,4 \%$ \\
\hline
\end{tabular}
and evaporative demand.

Table 2. Representation of effective stocks estimated by "water budget method".

$*$ Stock $_{\text {eff }}=$ efficient stock $=$ efficient Precipitation $=$ Run off + Infiltration, $*$ APr=Annual Precipitation.

\subsection{Recharge Estimation from Water Table Fluctuations (WTF) Calculations}

The water table fluctuations that appear spatially as a response of the average recharge, can, however, also be useful to determine long-term changes in recharge caused by climate or by human actions (land-use dynamics, dam, irrigation, etc.). This method consists in identifying a cause, the infiltration by the analysis of its effects, which are groundwater level variations in shallow aquifers. It is based on the assumption that the rise in groundwater levels in unconfined aquifers is related to the recharge water that reaches the aquifer.

This recharge is calculated from the formula:

$$
\mathrm{R}=\mathrm{Sy} \cdot \frac{\mathrm{dh}}{\mathrm{dt}}
$$

With, $\mathrm{S}_{\mathrm{y}}=$ Specific storage coefficient, $\mathrm{dh}=$ piezometric level variation and $\mathrm{dt}=$ time. This method has been used in various studies [34] and [35] and described in detail by [36]. It has been applied to a wide variety climatic conditions on steady-regime of shallow aquifer. Recharge rates estimated by this technique vary from $5 \mathrm{~mm} /$ year in the Tabalah basin of Saudi Arabia [37] to $247 \mathrm{~mm} /$ year in a small basin of eastern wetland region of United State [38]. The only difficulties in method applying are the determination of the representative value of $\mathrm{S}_{\mathrm{y}}$ which directly controls recharge estimated values and the assurance that water levels fluctuations are related to the recharge and not to pumping or evapotranspiration phenomena which can mainly question this hypothesis. To study the evolution of piezometric levels fluctuations in the alluvial aquifer (upper compartment), a monthly monitoring was carried out between 2011 and 2013. Piezometers are located respectively close to rivers (GA0072 and GA0069), near to hydraulic axis and hydro-agricultural perimeters (GA0068 and GA0083) and remote from rivers and irrigated fields (GA0002 and GA0120) (Figure 3a). The analysis of piezometric levels variations curves indicate recharge/discharge phases corresponding respectively to rainy season (July-October) and dry season which starts in November (Figure 3b). This seasonal alternation of groundwater recharge/discharge phases also coincides to flood and receding periods of surface water; that which would tend to prove a hydrodynamic relationship between Senegal River and shallow alluvial aquifer. However, the differences in level variations observed between these piezometers in upper compartment, could be related to precipitated water volumes, unconfined or confined aquifers characteristics (Nouakchottian and Inchirian 2), but also soil surface condition and at their distance to watercourses and hydro-agricultural perimeters. Through this analysis, we also found that hydro-agricultural perimeters, particularly ricegrowing areas when they are flooded, over several weeks, contribute to intensify the vertical percolation and maintain in charge the upper compartment of the alluvial aquifer (GA0083). These contributions are often characterized on intra-seasonal piezometric profiles by larger flood amplitudes and intermittent and irregular recharge/discharge peaks (Figure 3b). In the area, considering the representative 
average value $\mathrm{S}_{\mathrm{y}}$ of $20 \%$ and $10 \%$ respectively in dunes and alluvial plain [39], recharge calculations from groundwater levels fluctuations of alluvial aquifer were recorded in tables 3 and 4. They indicate recharge proportions in the upper compartment vary between 0-29percent of annual precipitation which correspond to values ranges already found in the alluvial plain by others methods in particular water balance methods. However, it must be remembered that these recharge rates recorded in the upper compartment of the alluvial aquifer are not only the result of infiltrated rainwaters. They also represent contributions of surface water or irrigation waters infiltrated, as shown by the seasonal piezometric levels monitoring (Figure $3 b$ ).

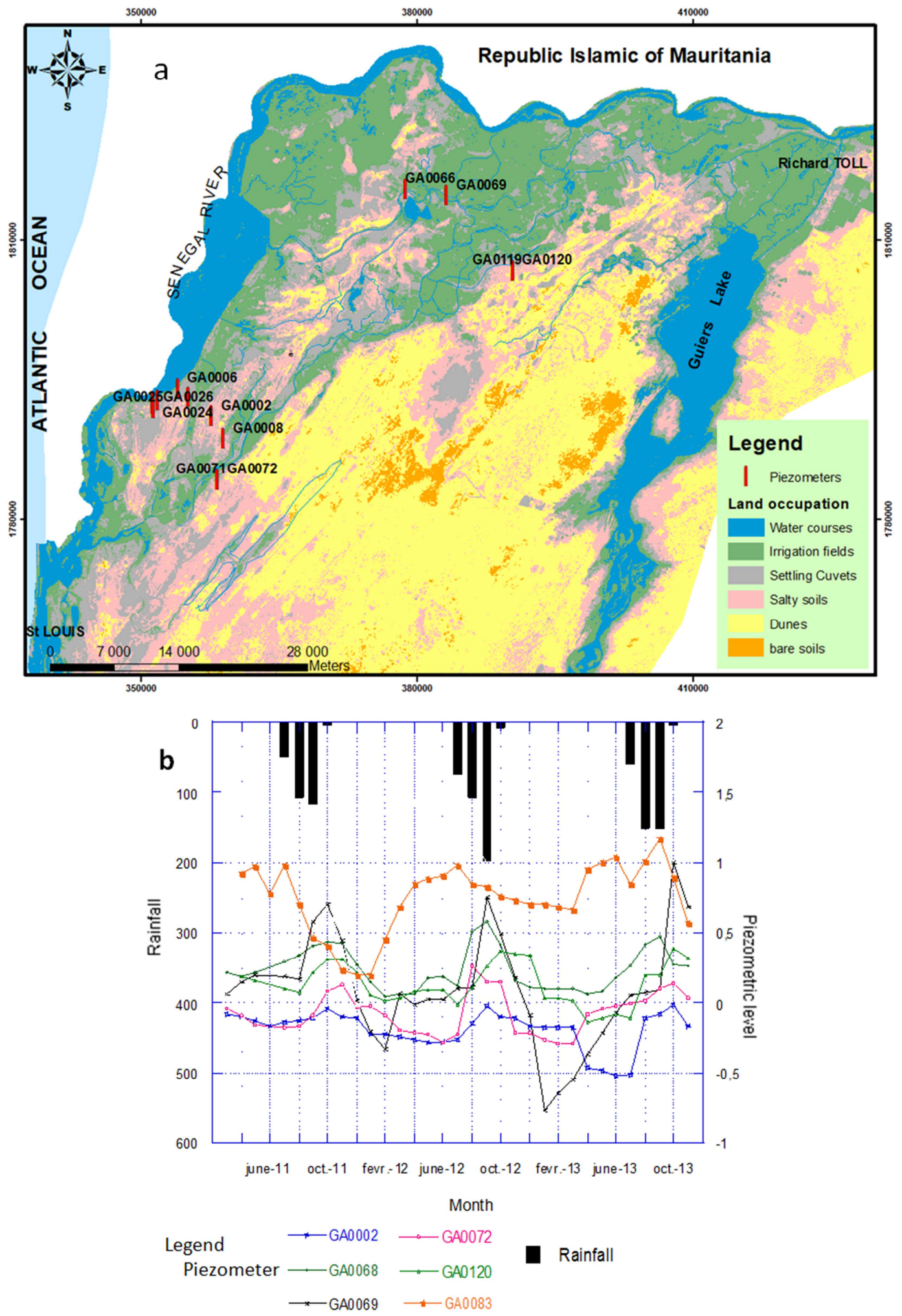

Figure 3. Piezometers localization (a) and piezometric monitoring of alluvial shallow groundwater (b). 
In dune systems, the piezometric levels monitoring (between July and November 2005) has shown that there are also inter-seasonal fluctuations which can be assimilated to rainfall contribution of groundwater recharges (rainfall only natural renewal source). This assumes that all rainfall regime variation causes a groundwater regime variation and therefore its level. Results consigned in table 4, indicate recharge proportions which are also getting closer to ranges values defined by water balance methods (in particular the "water budget method"). They are between 10-72 mm/year and represent $4-27 \%$ of annual rainfall. The highest recharge proportions are observed in the sandy sediments of Ogolian dunes. In this part, the water fraction infiltrated, which evidently serves to raise the water table levels, depends mainly on precipitated water volumes and aquifer depth.

Table 3. Recharge estimating from Water Table Fluctuation monitoring in the alluvial plain.

\begin{tabular}{|c|c|c|c|c|c|c|c|c|c|}
\hline \multirow{2}{*}{$\begin{array}{l}\text { Years } \\
\text { Piezometers }\end{array}$} & \multicolumn{3}{|c|}{$2011($ Precipitation $=276 \mathrm{~mm})$} & \multicolumn{3}{|c|}{$2012($ Precipitation $=387 \mathrm{~mm})$} & \multicolumn{3}{|c|}{$2013($ Precipitation $=366 \mathrm{~mm})$} \\
\hline & $\begin{array}{l}V h=d h / d t \\
(m)\end{array}$ & $\begin{array}{l}R=\mathrm{dh} / \mathrm{dt} * \mathrm{~S}_{\mathrm{y}} \\
(\mathrm{mm} / \text { year })\end{array}$ & $\begin{array}{l}\text { R/ APr } \\
(\%)\end{array}$ & $\begin{array}{l}V h=d h / d t \\
(\mathrm{~mm} / \text { year })\end{array}$ & $R=d h / d t * S_{y}$ & $\begin{array}{l}\text { R/APr } \\
(\%)\end{array}$ & $V h=d h / d t$ & $\begin{array}{l}R=d h / d t * S_{y} \\
(\mathrm{~mm} / \text { year })\end{array}$ & $\begin{array}{l}\text { R/ APr } \\
(\%)\end{array}$ \\
\hline GA0002 & 0,1 & 10 & $4 \%$ & 0,26 & 26 & $7 \%$ & 0,51 & 51 & 14 \\
\hline GA0069 & 0,52 & 52 & $19 \%$ & 0,73 & 73,1 & $19 \%$ & 1,07 & 107 & 29 \\
\hline GA0072 & 0,255 & 25,5 & $9 \%$ & 0,43 & 43 & $11 \%$ & 0,16 & 16 & 4 \\
\hline GA0120 & 0,215 & 21,5 & $8 \%$ & 0,17 & 17 & $4 \%$ & 0,47 & 47 & 13 \\
\hline GA0083 & 0,58 & 58 & $21 \%$ & 0,08 & 8 & $2 \%$ & 0,14 & 14 & 4 \\
\hline
\end{tabular}

$* \mathrm{dh}=$ Piezometric level variation, $\mathrm{dt}=$ time, ${ }^{*} \mathrm{~S}_{\mathrm{y}}=$ Specific storage coefficient $=0.10, \mathrm{R}=$ Annual recharge, $*$ Apr $=$ Annual Precipitation.

Table 4. Recharge estimating from WTF monitoring in the alluvial plain and dunes formations in 2005.

\begin{tabular}{|c|c|c|c|c|c|c|c|}
\hline \multicolumn{4}{|l|}{ Dunes Formation } & \multicolumn{4}{|l|}{ Alluvial Plain } \\
\hline Wells name & $\begin{array}{l}V h=d h / d t \\
(m / \text { year })\end{array}$ & $\begin{array}{l}R: S_{y}{ }^{*} d h / d t \\
(\mathrm{~mm} / \text { year })\end{array}$ & $\begin{array}{l}\text { R/Apr } \\
(\%)\end{array}$ & Wells name & $\begin{array}{l}\mathrm{Vh}=\mathrm{dh} / \mathrm{dt} \\
(\mathrm{m} / \text { year) }\end{array}$ & $\begin{array}{c}\mathbf{R} \\
\text { (mm/year) }\end{array}$ & $\begin{array}{l}\text { R/ Apr } \\
(\%)\end{array}$ \\
\hline Gantour & 0,25 & 50 & $18 \%$ & Savoigne & 0,22 & 22 & 8 \\
\hline Ricott & 0,15 & 30 & $11 \%$ & Dagana & 0,3 & 30 & 11 \\
\hline Keur Demba Diam & 0,28 & 56 & $21 \%$ & Ndiaréme & 0,55 & 55 & 20 \\
\hline Takhembeut & 0,19 & 38 & $14 \%$ & Mbilor & 0,13 & 13 & 5 \\
\hline Nialakhar & 0,24 & 48 & $18 \%$ & Mbilor & 0,74 & 74 & 27 \\
\hline Mbakhana & 0,36 & 72 & $27 \%$ & Keur Mbaye & 0,43 & 43 & 16 \\
\hline Lampsar & 0,22 & 44 & $16 \%$ & Ndombo & 0,79 & 79 & 29 \\
\hline Tiadem & 0,08 & 16 & $6 \%$ & Ntiago & 0,16 & 16 & 6 \\
\hline \multirow[t]{2}{*}{ Nguenth } & 0,05 & 10 & $4 \%$ & Téméye Salam & $-0,32$ & 0 & 0 \\
\hline & & & & El Quouss & 0,25 & 25 & 9 \\
\hline
\end{tabular}

$* \mathrm{Sy}=$ Specific storage coefficient (dune $=0.15$ and alluvial plain=0.10), $\mathrm{R}=$ Annual recharge, $*$ APr=Annual Precipitation $(271$ mm $)$.

\subsection{Recharge Estimation by Using Isotopic Tracers of the Water Molecule}

The isotopic techniques contributing to aquifers recharge evaluation, give either qualitative indications on the recharge existence or not, or either quantitative indications by making it possible to calculate recharge rates which is essential, to define the recharge spatial variability and the groundwater flow context. The knowledge of recharge rates and distributions is sometimes useful for managing water resources in a rational way and distinguishing renewable groundwater, suitable for sustainable use. To estimate the direct recharge, geochemical and isotopic tracing methods are more promising in semi-arid and arid regions than other methods that often have the most shortcomings [5, 17, 4042]. Their application in hydrological and hydrogeological investigations, has been observed in different contexts and through the world [43-45]. This is a very valuable tool to provide information on sources, renewal and aquifers flow rhythms. Environmental isotopes such as tritium are the most used for assessing aquifer recharge [4, 46], and [47]. The tritium use in saturated or unsaturated zones of aquifers has revealed, through numerous studies, the relevance and effectiveness of these isotopic tools in recharge estimating in arid and semi-arid environments.

\subsubsection{Recharge Estimation by Using Stable Isotopes of the Water Molecule}

i. Brute recharge estimation model proposed by [48].

The near-ideal conservation of stable isotopic composition of the water molecule $\left(\delta^{2} \mathrm{H}\right.$ or $\left.\delta^{18} \mathrm{O}\right)$ that can help identify recharge and circulation zones within systems, has been successfully used in many arid regions studies. These tracers can be easily measured and are used as indicators of evaporation or condensation phenomena, but also to determinate water mixing ratios of different origins or to estimate recharge rates in both saturated and unsaturated areas. In delta dune systems, there are often evaporation effects which are at the origin of groundwater deviation with regard to World Meteoric Line (WML) or LML (Local Meteoric Line). In the $\delta^{18} \mathrm{O}-\delta \mathrm{D}$ diagram, groundwater 
isotopic compositions are distributed below and parallels to WML (Figure 4). It is this groundwater deviation or $\Delta \delta$ shift which is used to calculate the brute recharge. This brute recharge would correspond to moisture evaporated mixtures from the ground with the rainwater that infiltrates and moves the soil residual water downwards. Thus, the mixed water will reach the groundwater. The $\Delta \delta$ shift which is normally established from measurement on the soil interstitial water at different depths. It can indeed be considered that the upper portion of shallow groundwater corresponds to soil interstitial waters at different depths. This approach has been applied only in dune formations which are a similar climatic context, where authors had developed this relationship with rainfall as only groundwater recharge source.

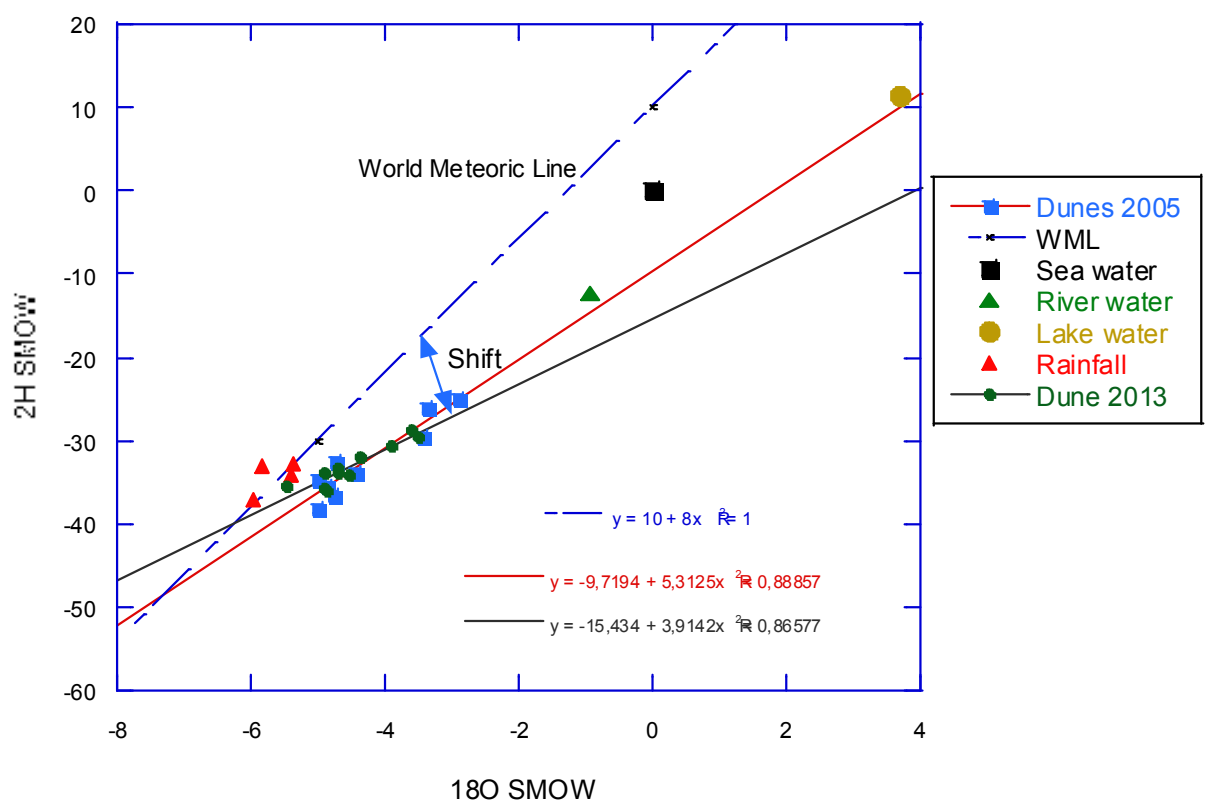

Figure 4. Relation Oxygen-18 $\left(\delta^{18} \mathrm{O}\right)$ and Deuterium $\left(\delta^{2} H\right)$ of groundwater in dunes formations.

This model has been establish after experimentation on 4 profiles in Australia, was proposed by [48] which give an empirical relation between $\Delta \delta$ shift, annual recharge $(\mathrm{R})$ and soil thickness:

$$
\Delta \delta \text { shifts }=\text { Soil thickness } /(\text { recharge })^{1 / 2}
$$

$\Delta \delta$ shifts $=\delta^{2} \mathrm{H}-\mathrm{m} \delta{ }^{18} \mathrm{O}$, represents the $\delta^{2} \mathrm{H}$ or $\delta^{18} \mathrm{O}$ displacement with respect to Local Meteoric Line (where $\mathrm{m}$ is the LML slope). The LML slope $(\mathrm{m}=7.9)$ has not been calculated; it was taken from results of [49], which have analyzed and determined isotope data from rainfall collected through Senegal in particularly in the area. The results of calculations indicate in dune formations that recharge values are ranging respectively from $0.2-101.3 \mathrm{~mm} /$ year in 2005 and $0.1-119.4 \mathrm{~mm} /$ year in 2013 (Table 5). These recharge values which represent $0.1-19 \%$ of annual rainfall, can go punctually up to reach $37 \%$ and $33 \%$ (respectively in 2005 and 2013) in the areas where market gardening cultures are highly developed. This indicates that these recharge proportions also depend in dunes formations to evaporative demands and human activities (withdraw, market gardening, irrigation, etc.). These results are almost near to values ranges found by in both "water budget" and piezometric level fluctuations methods $(0.1-18 \%$ up to $27 \%$ in 2005$)$.

Table 5. Recharge estimation by using stable isotope of the water molecule in dune formations.

\begin{tabular}{|c|c|c|c|c|c|c|}
\hline Wells name & $\delta^{18} \mathrm{O}$ & $\delta^{2} \mathbf{H}$ & $\Delta \delta=\delta^{2} H-m^{18} O$ & $\mathbf{E}(\mathbf{m})$ & $R(\mathrm{~mm} /$ year $)$ & R/ Apr (\%) \\
\hline \multicolumn{7}{|c|}{ year 2005} \\
\hline Gantour & $-4,43$ & $-33,8$ & 1,32 & 9,43 & 50,3 & 19 \\
\hline Ricott & -5 & $-34,6$ & 5,05 & 3,95 & 0,6 & 0,2 \\
\hline Keur Demba Diam & $-4,37$ & $-32,1$ & 2,55 & 11,76 & 21,2 & 8 \\
\hline Takhembeut & $-5,01$ & $-38,3$ & 1,42 & 4,94 & 11,9 & 4,4 \\
\hline Ndialakhar & $-4,86$ & $-35,4$ & 3,14 & 5,48 & 3,0 & 1,1 \\
\hline Nguenth & $-4,72$ & $-32,6$ & 4,82 & 2,8 & 0,3 & 0,1 \\
\hline Lampsar & $-4,77$ & $-36,5$ & $\begin{array}{c}1,32 \\
\text { year } 2013\end{array}$ & 13,35 & 101,3 & 37 \\
\hline Gantour & $-4,35$ & $-31,87$ & 2,62 & 9,2 & 12,3 & 3,4 \\
\hline Ricott & $-4,89$ & $-33,95$ & 4,82 & 3,9 & 0,7 & 0,2 \\
\hline Merry & $-4,41$ & $-31,66$ & 3,31 & 15,68 & 22,4 & 6,1 \\
\hline Obogg & $-4,90$ & $-35,64$ & 3,21 & 16,64 & 26,8 & 7,3 \\
\hline Keur Demba Diam & $-4,52$ & $-34,05$ & 1,79 & 11,16 & 38,7 & 11 \\
\hline
\end{tabular}




\begin{tabular}{lllllll}
\hline Wells name & $\boldsymbol{\delta}^{\mathbf{1 8}} \mathbf{O}$ & $\boldsymbol{\delta}^{\mathbf{2}} \mathbf{H}$ & $\Delta \boldsymbol{\delta}=\boldsymbol{\delta}^{\mathbf{2}} \mathbf{H}-\mathbf{m}^{\mathbf{1 8}} \mathbf{O}$ & $\mathbf{E}(\mathbf{m})$ & $\mathbf{R}(\mathbf{m m} / \mathbf{y e a r})$ & $\mathbf{R} / \mathbf{A p r}(\mathbf{\%})$ \\
\hline Diamar & $-4,51$ & $-32,43$ & 3,33 & 10,16 & 9,3 & 2,5 \\
Takhmbeut & $-4,69$ & $-33,99$ & 3,20 & 5,01 & 2,4 & 0,7 \\
Ndialakar & $-4,58$ & $-34,65$ & 1,66 & 5,22 & 9,8 & 2,7 \\
Lampsar & $-4,85$ & $-36,09$ & 2,37 & 12,86 & 29,4 & 8,0 \\
Nguenth & $-5,47$ & $-35,37$ & 8,00 & 2,75 & 0,1 & 0,0 \\
Tiadem & $-4,70$ & $-33,45$ & 3,82 & 2,94 & 0,6 & 0,2 \\
\hline
\end{tabular}

$* \delta^{18} \mathrm{O}=18$ Oxygen contents, $* \delta^{2} \mathrm{H}=$ Deuterium contents, $\Delta \delta=$ Delta Shift, $\mathrm{E}=$ Groundwater depth, $\mathrm{R}=$ Annual recharge, APr= Annual Precipitation.

\section{ii. Mixing model}

The using of "Mixing model" as recharge indicator, assumes that rainfall height-level rise amplitude relationship is also dependent on several other factors in addition to annual rainfall. This model has been applied to alluvial plain characterized by various groundwater recharge sources (rivers, irrigation water, rainfall, etc.). The mixing model application is based on isotope signatures of different groundwater recharge sources in order to determinate their relative contribution. In the model, two end-members was used to calculations ( $\mathrm{a}=$ rainfall particularly in small dunes and unconfined floodplain and $b=$ riverbank not concerned by irrigation). Conservative tracers such as $\delta^{18} \mathrm{O}, \delta^{2} \mathrm{H}$ are often used [50] according to the following equation (8):

$$
\mathrm{Xs}=\mathrm{FaXa}+\mathrm{FbXb} \text { and } \mathrm{Ys}=\mathrm{FaYa}+\mathrm{FbYb}
$$

or $X_{s}$ et $Y_{s}=$ tracers concentration $X$ or $Y$ in the sampling; $X_{n}$ et $Y_{n}=$ tracers concentration $X$ or $Y$ in each "end-member" $n$ $(n=a, b) ; F_{n}=$ Fraction in each end-member $n$ in the sampling $(\mathrm{n}=\mathrm{a}, \mathrm{b})$. With $\mathrm{Fb}$ may be rewritten as:

$$
\mathrm{Fb}=(1-F a)
$$

By integrating equations (8) and (9):

$$
\begin{gathered}
\mathrm{X}_{\mathrm{s}}=\mathrm{F}_{\mathrm{a}} \mathrm{X}_{\mathrm{a}}+\mathrm{F}_{\mathrm{b}} \mathrm{X}_{\mathrm{b}} \text { or } \mathrm{X}_{\mathrm{s}}=\mathrm{F}_{\mathrm{a}} \mathrm{X}_{\mathrm{a}}+\left(1-\mathrm{F}_{\mathrm{a}}\right) * \mathrm{X}_{\mathrm{b}} \\
\mathrm{Xs}-\mathrm{X}_{\mathrm{b}}=\mathrm{Fa}^{*}\left(\mathrm{X}_{\mathrm{a}}-\mathrm{X}_{\mathrm{b}}\right) \text { with } \mathrm{Fa}=\frac{(\mathrm{Xs}-\mathrm{Xb})}{(\mathrm{X} \mathrm{X}-\mathrm{Xb})} \text { and } \mathrm{F}_{\mathrm{b}}=1-\mathrm{F}_{\mathrm{a}}
\end{gathered}
$$

The results are recorded in Table 6. Thus, we have consider average values from surface water sampled $\left(\delta^{18} \mathrm{O}=\right.$ -1.98 and $\delta^{2} \mathrm{H}=-18.69$, end-member $\left.=\mathrm{a}\right)$ and from rainwater collected by [48] $\left(\delta^{18} \mathrm{O}=-5.5\right.$ and $\delta^{2} \mathrm{H}=-36$, end-member $=$ b). Results indicate that the renewal from rivers contribution vary respectively between $52-100 \%$ in 2013 (after rainy season) and between $81-100 \%$ in 2005 (dry season). But these recharge proportions are not too stretchy especially towards small dunes formation of which rainfall contribution is more important. It can represent, according to periods between 8 and $42 \%$ of recharge proportion (Table 6). This table indicates that recharge proportions sometimes highlight groundwater vulnerability in these sectors face to surface pollution. These results can give recharge indicators that can ultimately support the application of quantitative estimation methods for recharge rate calculation such as for example: the WTF method. If we consider results of recharge calculations from water table fluctuations, we could deduce in 2005 , the relative end-member contribution to shallow groundwater recharge in the alluvial plain (Table 7). This table indicates that recharge proportions provided by rainfall are similar to those estimated by other methods in dunes and in semi-confined alluvial plain sediments (varying between $1-19 \%$ of annual precipitation). Whereas in other sectors of the alluvial plain close to surface water (river, lake, irrigation channels; etc) recharge average values may be greater, varying between $19-38 \%$ of annual precipitation. In summary, we can therefore indicate that recharge estimation methods from stable isotopes of the water molecule is very useful but can be approximate and difficult to apply in some cases. The method may have limitations related to: signature changes generated by large diameters of wells where groundwater evaporation may occur and initial isotopic compositions of each end-member that must be followed

\begin{tabular}{|c|c|c|c|c|c|c|c|c|c|}
\hline \multirow{2}{*}{ Well Name } & \multicolumn{5}{|c|}{ Dry season } & \multicolumn{4}{|c|}{ After rainy season } \\
\hline & $\delta^{18} \mathrm{O}$ & $\delta^{2} \mathbf{H}$ & $\mathbf{F a}$ & $\mathbf{F b}$ & Well Name & $\delta^{18} \mathrm{O}$ & $\delta^{2} \mathbf{H}$ & $\mathbf{F a}$ & $\mathbf{F b}$ \\
\hline Savoigne & $-1,07$ & $-14,1$ & 100,0 & 0,0 & Dagana & $-2,27$ & $-20,49$ & 91,8 & 8,2 \\
\hline Dagana & $-1,66$ & $-17,9$ & 100,0 & 0,0 & Ndiaréme & $-1,52$ & $-16,62$ & 100,0 & 0,0 \\
\hline Ndiaréme & $-2,27$ & $-21,4$ & 91,8 & 8,2 & Mbilor & $-0,61$ & $-12,8$ & 100,0 & 0,0 \\
\hline Mbilor & $-0,59$ & $-11,7$ & 100,0 & 0,0 & Keur Mbaye & $-0,58$ & $-11,71$ & 100,0 & 0,0 \\
\hline Keur Mbaye & $-1,43$ & $-17,2$ & 100,0 & 0,0 & Ndombo & $-2,62$ & $-21,99$ & 81,8 & 18,2 \\
\hline Ndombo & $-1,67$ & -18 & 100,0 & 0,0 & Thiago & $-2,37$ & $-20,37$ & 88,9 & 11,1 \\
\hline Téméye Salam & $-1,08$ & $-14,8$ & 100,0 & 0,0 & Foss & 0,26 & $-6,81$ & 100,0 & 0,0 \\
\hline Mbakhana & $-1,09$ & $-14,5$ & 100,0 & 0,0 & Gueumbeul & $-3,43$ & $-27,01$ & 58,8 & 41,2 \\
\hline Gueumbeul & $-2,29$ & $-22,1$ & 91,2 & 8,8 & Mbakhana & $-1,45$ & $-16,61$ & 100,0 & 0,0 \\
\hline \multirow[t]{3}{*}{ El Quouss } & $-3,42$ & $-29,5$ & 59,1 & 40,9 & GA119 & $-2,02$ & $-18,15$ & 98,9 & 1,1 \\
\hline & & & & & GA001 & $-1,61$ & $-18,56$ & 100,0 & 0,0 \\
\hline & & & & & GA004 & $-0,71$ & $-11,47$ & 100,0 & 0,0 \\
\hline
\end{tabular}
over a long period in order to have representative values in calculations.

Table 6. Estimation of River and rainfall contributions in alluvial aquifer recharge.

$* \delta^{18} \mathrm{O}=18$ Oxygen contents, ${ }^{*} \delta^{2} \mathrm{H}=$ Deuterium contents, $\mathrm{Fa}=$ River contribution, $* \mathrm{Fb}=\mathrm{Precipitation}$ contribution. 
Table 7. Recharge proportions estimation of end-member by using Water Table Fluctuation calculations (WTF).

\begin{tabular}{|c|c|c|c|c|c|c|c|}
\hline \multirow{2}{*}{ Well Name } & \multirow{2}{*}{$R=\mathbf{d h} / \mathrm{dt}(\mathrm{mm} / \mathrm{an})$} & \multicolumn{3}{|c|}{ River contribution } & \multicolumn{3}{|c|}{ Rainfall contribution } \\
\hline & & Fa (mm/an) & C. V (mm) & R/Apr (\%) & Fb (mm/an) & C. V mm & R/ Apr (\%) \\
\hline Savoigne & 58,44 & 100,0 & 58,4 & 21,6 & 0,0 & 0,0 & 0,0 \\
\hline Dagana & 79,89 & 100,0 & 79,9 & 29,5 & 0,0 & 0,0 & 0,0 \\
\hline Ndiaréme & 61,8 & 91,8 & 56,7 & 20,9 & 8,2 & 5,1 & 1,9 \\
\hline Mbilor & 71,36 & 100,0 & 71,4 & 26,3 & 0,0 & 0,0 & 0,0 \\
\hline Keur Mbaye & 101 & 100,0 & 101,0 & 37,3 & 0,0 & 0,0 & 0,0 \\
\hline Ndombo & 78,34 & 100,0 & 78,3 & 28,9 & 0,0 & 0,0 & 0,0 \\
\hline Thiago & 80,01 & 100,0 & 80,0 & 29,5 & 0,0 & 0,0 & 0,0 \\
\hline Téméye Salam & 81,76 & 100,0 & 81,8 & 30,2 & 0,0 & 0,0 & 0,0 \\
\hline Mbakhana & 102,1 & 100,0 & 102,1 & 37,7 & 0,0 & 0,0 & 0,0 \\
\hline Gueumbeul & 57,1 & 91,2 & 52,1 & 19,2 & 8,8 & 5,0 & 1,9 \\
\hline El Quouss & 120,69 & 59,1 & 71,3 & 26,3 & 40,9 & 49,4 & 18,2 \\
\hline
\end{tabular}

$* \mathrm{R}=$ recharge estimated by WTF, $\mathrm{dh}=$ Piezometric variation, $\mathrm{dt}=$ time, $\mathrm{Fa}=$ River contribution, $\mathrm{C} . \mathrm{V}=$ Contribution volume, ${ }^{*} \mathrm{Fb}=\mathrm{Precipitation}$ contribution, *APr=Annual Precipitation.

\subsubsection{Recharge Estimation by Using Tritium}

Tritium ${ }^{3} \mathrm{H}$, as historical tracer or event marker, has been abundantly introduced into the atmosphere by nuclear bombs. However, over time tritium concentrations produced by bombs have been greatly reduced by radioactive decay (groundwater case) or by dilution effect from marine vapors (for precipitation). In the southern hemisphere, where tritium concentrations in precipitation were in lower order of magnitude than in the northern hemisphere [51], it is often difficult to distinguish ${ }^{3} \mathrm{H}$ produced by bombs and current ${ }^{3} \mathrm{H}$ concentrations in precipitation. The dating method of groundwater, by using chemical substances or isotopes, is based on concentration measurements of these tracers in water. Tritium has the advantage that chemical processes in the aquifer do not affect it, unlike other radiogenic tracers for which tracers are dated, but not water itself [52]. In the past, tritium (radioactive isotope of hydrogen and intimate tracer of water) has been widely used to estimate the time interval elapsed with respect to the corresponding recharge and the recharge rate in saturated and unsaturated zones $[53,54]$.

i. Exponential Model

Groundwater age estimation is based on the knowledge of initial tritium concentrations in precipitation at recharge time $\left(\mathrm{a}_{0}{ }^{3} \mathrm{H}\right.$ : chronic measurements since thermonuclear tests $)$ and residual tritium due to disintegration, measured in groundwater at sampling time $\left(\mathrm{a}_{\mathrm{t}}{ }^{3} \mathrm{H}\right)$. The exponential model is expressed by this relation:

$$
a_{t}{ }^{3} H=a_{0}{ }^{3} H * \mathrm{e}^{-\lambda \mathrm{t}} \text { with } \lambda=\ln 2 / \mathrm{T}
$$

Replacing T (half-life) with 12.43 years, the equation (10) becomes:

$$
\mathrm{t}=17,93 \ln \frac{\mathrm{a}_{\mathrm{t}}{ }^{3} \mathrm{H}}{\mathrm{a}_{0}{ }^{3} \mathrm{H}}
$$

with $\mathrm{t}=$ average groundwater residence time or «average transit time » with better expresses the time interval elapsed with respect to the recharge concerned. $\left(\mathrm{a}_{\mathrm{t}}^{3} \mathrm{H}\right)$ depends on the tritium amount in the atmosphere when the precipitation is formed and the time interval during which the water passes from the soil surface to the aquifer (sampling point). $\left(\mathrm{a}_{0}{ }^{3} \mathrm{H}\right)$ is the tritium concentration in precipitation at recharge time. It represents weighted annual tritium contents in precipitation approximately over a period of 50 years. Recently, [55] showed that weighted annual tritium contents returned to almost constant precipitation in the early 2000s. In West Africa, they vary between $0-5 \mathrm{UT}\left(\mathrm{a}_{0}{ }^{3} \mathrm{H}\right)$. Considering the (t) average residence time derived from the exponential model, we can in a simple approach, estimate the recharge by the following equation:

$$
\mathrm{R}=\frac{\sum n i H i}{t}
$$

(t): average residence time; (ni): efficient porosity and (Hi): aquifer thickness which considers the vertical between the surface and the saturated zone. This calculation model theoretically based on the transit time admits that pumped wells produce mixtures of different water ages or transit time from various penetrated lithological units. This is an approach that has been used in major groundwater recharge studies in Africa and around the world. Taking into account the annual chronic of tritium contents in Senegal rainwater (Global Network Isotope in Precipitation, 2012-2014), an approximate average value of $\mathrm{a}_{0}{ }^{3} \mathrm{H}=4$ UT is considered in the calculations. Results recorded in Tables 7 and 8 , indicate recharge proportions in dune formations varying respectively between $12-47 \%$ in 2005 and $7-30 \%$ of annual rainfall. These values ranges are almost similar to those defined by hydrological balance method of [31]. However, this slight increase in recharge ratios observed in the dry season (2005) could justify the recharge part induced by market gardening activities practiced during this period in dunes formation (example in Ricott, Gantour, Lampsar wells, etc.). Conversely, in the alluvial plain, the model application indicates recharge proportions varying respectively between $0-18 \%$ and $3-18 \%$ of annual precipitation in 2005 and 2013 (Table 7) which also fall within defined ranges by other methods.

In this study, we also compared the results of recharge calculation from exponential model with those mathematical models, based on recharge calculation from tritium, which depend to aquifers hydrogeological characteristics:

ii. Mixing Well Model

This renewal rate estimation model was introduced by [56] and taken up by [2]. This method has been used in main 
studies of groundwater recharge in sub-Saharan Africa. These authors proposed the following formulation to estimate recharge rates:

$$
3 H g(i)=(1-R n) * 3 H g(i-1) e^{-\lambda t}+R n * 3 H p(i)
$$

$\lambda$ : Decay constant $\left(1.2110^{-4}\right),{ }^{3} \mathrm{Hg}$ (i) the tritium concentration of the water table in year $\mathrm{i} ;{ }^{3} \mathrm{Hp}$ (i) the tritium concentration from precipitation to year $\mathrm{i}$; Rn: renewal rate which is defined as the percentage of the aquifer which has been renewed each year. After nuclear tests in the atmosphere, the formulation admits that ${ }^{3} \mathrm{H}$ concentration in precipitation remains constant, under such conditions renewal rates are constant and will produce at steady-state ${ }^{3} \mathrm{H}$ concentrations in groundwater. The formulation is given by:

$$
3 H g=\frac{3 H p}{1+\frac{\lambda}{R n}}
$$

\begin{tabular}{|c|c|c|c|c|c|c|c|c|}
\hline \multirow[b]{2}{*}{ Well name } & \multicolumn{5}{|c|}{ Year $2005 \mathrm{APr}=241 \mathrm{~mm}$} & \multicolumn{3}{|c|}{ Year $2013 \mathrm{APr}=366 \mathrm{~mm}$} \\
\hline & $\mathbf{T}$ (year) & $\mathbf{E}(\mathbf{m})$ & $E *$ ne ne $=0.15$ & $\begin{array}{l}R=\left(E^{*} n e\right) / t(\mathrm{~mm} / \\
\text { year })\end{array}$ & $\begin{array}{l}\text { R/ APr } \\
(\%)\end{array}$ & $E *$ ne & $\begin{array}{l}R=\left(E^{*} \text { ne }\right) / t \\
\text { mm/ year }\end{array}$ & $\mathbf{R} / \mathbf{A P}(\%)$ \\
\hline Savoigne & 2,4 & 3,13 & 0,313 & 13,10 & 4,8 & nd & nd & nd \\
\hline Dagana & 2,4 & 5,25 & 0,525 & 21,43 & 7,9 & 28,67 & 19,11 & 5,2 \\
\hline Ndiarém & 2,4 & 3,5 & 0,35 & 14,64 & 5,4 & 34,05 & 22,70 & 6,2 \\
\hline Mbilor & 3,4 & 4,95 & 0,495 & 14,35 & 5,3 & 43,10 & 28,73 & 7,8 \\
\hline Keur Mbaye & 1,9 & 9,09 & 0,909 & 48,10 & 17,7 & 97,72 & 65,14 & 17,8 \\
\hline Ndombo & 1,4 & 5,32 & 0,532 & 38,00 & 14,0 & 91,70 & 61,13 & 16,7 \\
\hline Ntiago & 1,4 & 5,55 & 0,555 & 39,64 & 14,6 & 41,06 & 27,37 & 7,5 \\
\hline Téméye Salam & 4 & 6,7 & 0,67 & 16,75 & 6,2 & 52,67 & 35,11 & 9,6 \\
\hline Gueumbeul & 5,7 & 2 & 0,4 & 6,93 & 2,5 & 20,53 & 13,69 & 3,7 \\
\hline Foss & 18,8 & 4,39 & 0,439 & 2,33 & 0,8 & 16,68 & 11,12 & 3,0 \\
\hline
\end{tabular}

Table 8. Recharge estimation by using average transit time in alluvial plain aquifer.

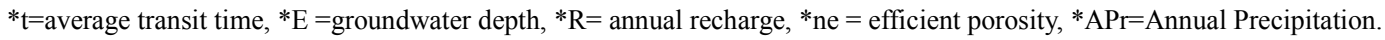

\begin{tabular}{|c|c|c|c|c|c|c|c|c|}
\hline \multirow[b]{2}{*}{ Well name } & \multicolumn{4}{|c|}{ Year 2005} & \multicolumn{4}{|l|}{ Year 2013} \\
\hline & T (year) & $\mathbf{E}(\mathbf{m})$ & $\begin{array}{l}R=\left(E^{*} \text { ne }\right) / t \\
\text { mm/an ne }=0,20\end{array}$ & $\begin{array}{l}\text { R/ APr } \\
(\%)\end{array}$ & Well name & t (year) & $\begin{array}{l}R=\left(E^{*} n e\right) / t \\
(\mathrm{~mm} / \text { year })\end{array}$ & $\begin{array}{l}\text { R/ APr } \\
(\%)\end{array}$ \\
\hline Gantour & 18,82 & 9,43 & 100 & 37 & Gantour & 18,82 & 23,5 & 6 \\
\hline Ricott & 6,4 & 3,95 & 123 & 46 & Ricott & 6,4 & 109,1 & 30 \\
\hline Keur D Diam & 31,25 & 11,76 & 75 & 28 & Keur D Diam & 31,25 & 37,3 & 10 \\
\hline Takhembeut & 7,72 & 4,94 & 128 & 47 & Takhembeut & 7,72 & 29,9 & 8 \\
\hline Nguenth & 9,92 & 2,8 & 56 & 21 & Nguenth & 9,92 & 25,1 & 7 \\
\hline Tiadem & 9,92 & 1,68 & 34 & 12 & Tiadem & 9,92 & 61,7 & 17 \\
\hline Lampsar & 26,75 & 13,35 & 100 & 37 & Lampsar & 26,75 & 46,5 & 13 \\
\hline Obogg & nd & nd & nd & nd & Obogg & 53,71 & 92,8 & 25 \\
\hline Diamar & nd & nd & nd & nd & Diamar & 16,42 & 58,4 & 16 \\
\hline
\end{tabular}

Table 9. Recharge estimation by using average transit time in dunes aquifer.

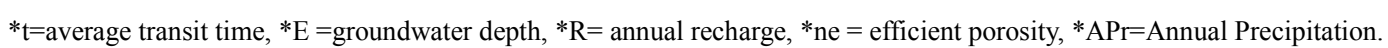

Thus, ${ }^{3} \mathrm{H}$ concentrations in groundwater increase with increasing renewal rates. ${ }^{3} \mathrm{Hg}$ values calculated are reasonable to be estimated at steady-state and each ${ }^{3} \mathrm{H}$ concentration produces a single value of renewal rate $(\mathrm{Rn})$. The recharge rate $(R)$ is related to the renewal rate $(R n)$ by the aquifer thickness (b) and the porosity (n): $R=R n^{*} b^{*} n$ (14). The results indicate that recharge proportions in dunes and alluvial plain are conform to those defined by the exponential model (Table 9) and practically by all other methods (water table fluctuation and water balance methods, etc.).

iii. Leduc et al., 1996 Model

Authors have proposed a simple model that seems adapted to the recharge mode of Sahelian aquifers [57]. This model takes into account the tritium radioactive decay and represents the annual evolution of isotopic composition according to volumes and previous activities of the aquifer and the infiltrated rainfall until the sampling date. Considering the tritium radioactive decay from groundwater between 2005 and 2013. This model makes it possible to calculate annual renewal rates on each elementary volume assumed to be homogeneous. The average tritium content in the aquifer during year (i) is calculated by:

$$
\operatorname{An}(\mathrm{i})=(1-\operatorname{Tri}) * \operatorname{An}(\mathrm{i}-1) \mathrm{e}^{-\ln 2 / \mathrm{T}}+\operatorname{Tr} \mathrm{i} * \operatorname{Ap}(\mathrm{i})
$$

Avec $A n_{i=}$ tritium content of the aquifer in 2013; $\operatorname{Tr}_{i}=$ aquifer renewal rate, $A n_{i-1}=$ tritium content of the aquifer in year $\mathrm{i}_{-1}$ corresponding to tritium content in 2005, $T=$ tritium period (12.43 years), Api $=$ tritium content of rainfall in year $i$.

The results (Table 10) nevertheless indicate recharge proportions fall within the ranges proposed by all other 
methods, in particular the water budgets, exponential model and the 'Well mixing model'. It must be remembered that the recharge calculation from tritium values is quite complex because it is difficult to determine the mass balance tritium and that the tritium short life can only date waters about 50 years old. Moreover, in spite of their relevance, these methods are becoming more and more difficult to use due to the thermonuclear tests cessation, reduction of tritium contents in rainwater and in the vapor phase during evapotranspiration where tritium is not conservative.

Table 10. Recharge proportions estimation from tritium contents.

\begin{tabular}{llll}
\hline & Alluvial Plain & & Dune Formation \\
\cline { 2 - 4 } & $\mathbf{2 0 0 5}$ & $\mathbf{2 0 1 3}$ & $\mathbf{2 0 0 5}$ \\
\hline Exponential model & $0-18 \%$ & $3-18 \%$ & $12-47 \%$ \\
Well mixing model proposed by [56] & $1-25 \%$ & $2-37 \%$ & $10-47 \%$ \\
Calculation model proposed by [57] & $4-16 \%$ & $3-30 \%$ & $2-18 \%$ \\
\hline
\end{tabular}

\section{Conclusion}

Infiltration rates calculated from water table fluctuations are generally given good estimations with values which fall defined ranges by recharge potential estimation determined from water balance methods. But investigations are still needed to control problems associated with the dispersion, the infiltration mechanism itself in relation to the mixing model and the preferential infiltration channels in the aquifers. The use of isotope tracing techniques in recharge rates estimation has also given quite interesting results, particularly in dunes, where the climatic characteristics are fairly similar to those where the applications have been validated (in arid zones or semi-arid). It remains, however, a fairly promising and reliable estimation method when in aquifers recharge sources are clearly defined and the representative data in calculations are well known (example: initial concentrations of each end-member, effective porosity measured on the aquifer matrix, etc.). The use of tritium in dune and alluvial aquifers, through many approaches, indicates that these aquifers contain recent water proportions which guaranteed a net recharge. The recharge proportions seem to agree with results of other estimation methods. The differences observed in calculations could be justified: either by application limits of models used in these cases or by a variety of recharge sources that depend exclusively on soil and subsoil surface conditions, seasonal context and human occupation.

\section{Acknowledgements}

We appreciate the support of the University of Avignon (France) through its Laboratory of Hydrogeology.

\section{References}

[1] Cook, P. G., Walker, G. R., Jolly, I. D. (1989). Spatial variability of groundwater recharge in a semi-arid region. $\mathrm{J}$ Hydrol 111: 195-212.

[2] Le Gal La Salle, C., Marlin, C., Leduc, C., Taupin, J. D., Massault, M., \& Favreau, G. (2001). Renewal rate estimation of groundwater based on radioactive tracers $\left({ }^{3} \mathrm{H},{ }^{14} \mathrm{C}\right)$ in an unconfined aquifer in a semi-arid area, Iullemeden Basin, Niger. Journal of Hydrology, 254 (1-4), 145-156.
[3] Scanlon, B. R., Keese, K. E., Flint, A. L., Flint, L. E., Gaye, C. B., Edmunds, W. M., \& Simmers, I. (2006): Global synthesis of groundwater recharge in semi-arid and arid regions. Hydrological Processes, 20 (15), 3335-3370.

[4] Leduc, C. (2003). Dynamiques hydrologiques en milieu semi aride (Habilitation à Diriger des Recherches). Université de Montpellier II, (81 p). France.

[5] Allison, G. B. (1988). A review of some of the physical, chemical and isotopic techniques available for estimating groundwater recharge. NATO ASI Ser., (Ser C 222), 49-72.

[6] Simmers, I. (ed.) (1988). Estimation of natural groundwater recharge. Reidel, Boston, $510 \mathrm{pp}$.

[7] Lerner, D. N., Issar, A. S., Simmers, I. (1990). Groundwater recharge, a guide to understanding and estimating natural recharge. International Association of Hydrogeologists, Kenilworth, Rep 8, 345 pp.

[8] Allison, G. B., Gee, G. W. and S. W. Tyler. (1994). Vadosezone techniques for estimating groundwater recharge in arid and semi-arid regions. Soil Science Society of America 578 Journal 58, 6-14.

[9] Scanlon, B. R., Healy, R. W., \& Cook, P. (2002). Choosing appropriate techniques for quantifying groundwater recharge. Hydrogeology Journal, 10 (1), 18-39.

[10] Kinzelbach, W., Aeschbach, W., Alberich, C., Goni, I. B., Beyerle, U., Brunner, P., Chiang, W. H., Rueedi, J., Zoellman, K. (2002). A Survey of Methods for Groundwater Recharge in Arid and Semi-Arid Regions, Early Warning and Assessment Report Series, UNEP/DEWA/RS.02-2. United Nations Environment Programme: Nairobi, ISBN 92-8070213180702133.

[11] Besbes, M., Dethomme J. P. \& De Marsily G., (1978). Estimating recharge from ephemeral streams in arid regions: a case study at Kairouan, Tunisia. Water Resour. Res. 14, 281290 .

[12] Gee, G. W., and Hillel, D. (1988). Groundwater recharge in arid regions: review and critique of estimation methods. Hydrol. Proc.2, 255-266.

[13] Gaye, C. B (1990). Etude isotopique et géochimique du mode de recharge par les pluies et de la décharge évaporatoire des aquifères libres sous climat semi-aride au Nord du Sénégal. Thèse Etat, Univ. Dakar.

[14] Allison, G. B., Gee, G. W. and Tyler, S. W. (1994). Vadosezone techniques for estimating groundwater recharge in arid and semiarid regions. Soil Science Society of America 578 Journal 58, 6-14. 
[15] Stephens, D. B. (1994). A perspective on diffuse natural recharge mechanisms in areas of low precipitation. Soil Sci Soc Am J 58: 40-48.

[16] Lerner, D. N. (1997). Groundwater recharge. In: Saether OM, de Caritat P (eds) Geochemical processes, weathering and groundwater recharge in catchments. AA Balkema, Rotterdam, pp 109-150.

[17] Simmers, I. (ed) (1997). Recharge of phreatic aquifers in (semi-) arid areas. AA Balkema, Rotterdam, 277 pp.

[18] Bredenkamp, D. B., Botha, L. J., van Tonder, G. J. and van Rensburg, H. J. (1995). Manual on Quantitative Estimation of Groundwater Recharge and Aquifer Storativity. Water Research Commission Report TT73/95, Pretoria. 407 pp.

[19] Stephens, D. B. (1996). Estimation of infiltration and recharge for environmental site assessment. API Publ 4643. Health and Environmental Sciences Department, Albuquerque, New Mexico.

[20] Sukhija, B. S., Nagabhushanam, P., Reddy, D. V. (1996). Groundwater recharge in semi-arid regions of India: an overview of results obtained using tracers. Hydrogeol J 4 (3): 50-71.

[21] Audibert, M. (1970). «Delta du fleuve Sénégal. Étude hydrogéologique. Projet hydro-agricole du bassin du fleuve Sénégal». Tome III: hydrogéologie, Tome IV: drainabilité, Rapport Projet AFR/REG 61. FAO/OERS.

[22] Illy, P. (1973). Étude hydrogéologique de la vallée du fleuve Sénégal. Projet hydro agricole du bassin du fleuve Sénégal. Rapport RAF/65061. p158.

[23] Tricart, J. (1961). Notice explicative de la carte géomorphologique du delta du Sénégal. Paris mémoire BRGM. n' ${ }^{\circ}$. 137.3 cartes en couleurs au 1/100000.

[24] Diaw, M. (2008). Approche hydrochimique et isotopique de la relation eau de surface/nappe et du mode de recharge de la nappe alluviale dans l'estuaire et la basse vallée du fleuve Sénégal: Identification des zones inondées par Télédétection et par traçage isotopique», Mem. Doctorat de Thèse $3^{\mathrm{e}}$ cycle FST/UCAD de Dakar, $210 \mathrm{p}$.

[25] Diaw, M., Faye, S., Maloszewski, P., Stichler, W. (2012). Isotopic and geochemical characteristics of groundwater in the Senegal River delta aquifer: implication of recharge and flow regime; Journal Environ. Earth Sci. DOI 10.1007/s12665-0100710-4 (article online).

[26] PASMI. (2008). Notice explicative de la carte géologique du Sénégal à $1 / 500000$, feuilles nord-ouest, nord-est et sud-ouest, Ministère des Mines, de l'Industrie, de l'AgroIndustrie et des PME, Direction des Mines et de la Géologie, Dakar.

[27] Epstein, S., Mayeda, T. K. (1953). Variations of ${ }^{18} \mathrm{O}$ content of waters from natural sources. Geochimical et Cosmochimical Acta. 4: 213-224.

[28] Coleman, M. L., Shepherd, T. J., Durham, J. J., Rouse, J. E., Moore, G. R. (1982). Reduction of water with zinc for hydrogen isotope analysis. Analytical Chemistry 54: 993-995.

[29] Thatcher, L., Janzer, V. J., Edwards, R. W. (1977). Methods for determination of radioactive substances in water and fluvial sediments. In: Techniques of Water Resources Investigations of the US Geological Survey. US Government Printing Office. Washington. DC. Chapter A5: 79-81.
[30] De Vries, J., \& Simmers, I. (2002). Groundwater recharge: an overview of processes and challenges. Hydrogeology Journal, $10(1), 5-17$.

[31] Camus, H. et Debuisson, J. (1964). Etude hydrogéologique des terrains anciens du Sénégal Oriental. Campagne 19621963. Rapport BRGM, Dakar. 64-06, 143p.

[32] Mall, I. (2017). Evaluation des ressources en eau dans le socle birrimien du Senegal oriental: approts des outils geochimiquess, geostatistiques, de la Teledection et des SIG, these de doctorat, universite Cheikh anta Diop, 213 pages.

[33] Thornthwaite, C. W. (1948). An approach towards a rational classification of climate, Geograph. Rev. 38, 55-94.

[34] Meinzer, O. E. and Steams N. D. (1928). A Study of Groundwater in the Pomperaug Basin, Connecticut, with Special Reference to Intake and Discharge. U. S. Geological Survey Water Supply Paper 597-B.

[35] Hall, D. W., Risser, D. W. (1993). Effects of agricultural nutrient management on nitrogen fate and transport in Lancaster County, Pennsylvania. Water Resour Bull 29: 55-76.

[36] Healy, R., Cook, P. (2002). Using groundwater levels to estimate recharge. Hydrogeology Journal, 10 (1), 91-109.

[37] Abdulrazzak, M. J., Sorman, A. U., Alhames, A. S. (1989). Water balance approach under extreme arid conditions - a case study of Tabalah Basin, Saudi Arabia. Hydrol Proc 3: 107-122 Allison GB, Stone WJ, Hughes MW (1985) Recharge in karst and dune elements of a semi-arid landscape as indicated by natural isotopes and chloride. J Hydrol 76: 126.

[38] Rasmussen, W. C., Andreasen, G. E. (1959). Hydrologic budget of the Beaverdam Creek Basin, Maryland. US Geol Surv Water-Supply Pap 1472: 106.

[39] OMVS/USAID. (1990). « Rapport de synthèse hydrogéologique du delta du fleuve Sénégal ». Projet OMVS/USAID 625-0958. Eaux souterraines. Rapport final. Dakar. Sénégal. Volume II. p73 et annexes.

[40] Fontes, J. Ch., Edmunds, W. M. (1989). The use of environmental isotope techniques in arid zone hydrology: a critical review. Technical documents in hydrology, IHP-III Project 5. 2, UNESCO, Paris, 75 pp

[41] Adanu, E. A. (1991). Source and recharge of groundwater in the basement terrain in the Zaria-Kaduaa area, Nigeria: applying stable isotopes. J. Afr. Earth Sci., 13 (2): 229-234.

[42] Sami, K. (1992). Recharge mechanisms and geochemical processes in a semi-arid sedimentary basin, Eastern Cape, South Africa. J. Hydrol., 139: 27-48.

[43] Vrbka, P., Bussert, R., Abdalla, O. A. E. (2008). Groundwater in north and central Sudan. In: Adelana, S. M. A., MacDonald, A. M. (Ed.), Applied Groundwater Studies in Africa. IAH Selected Papers in Hydrogeology 13, Taylor \& Francis, Amsterdam. 337-349.

[44] Rueedi, J., Brennwald, M. S., Purtschert, R., Beyerle, U., Hofer, M., Kipfer, R. (2005). Estimating amount and spatial distribution of groundwater recharge in the Iullemmeden basin (Niger) based on ${ }^{3} \mathrm{H},{ }^{3} \mathrm{He}$ and CFC-11 measurements. Hydrol. Process. 19, 3285-3298. 
[45] Goni, I. B. (2008). Estimating groundwater recharge in the southwestern sector of the Chad basin using chloride data. In: Adelana, S. M. A., MacDonald, A. M. (Ed.), Applied Groundwater Studies in Africa. IAH Selected Papers in Hydrogeology 13, Taylor \& Francis, Amsterdam. 323-336.

[46] Zimmermann, U., Ehhlat, D., and Munnich, K. W. (1967). Soil-water movement and evaportation changes in the isotopic composition of the water, In: Proceeding of the symposium of isotopes in Hydrology, Vienna, 1966, IAEA, Vienna, Austria, 567-584.

[47] Fontes, J. C. (1985). Some considerations on groundwater dating using environmental isotopes. Hydrogeology in the service of man (coll. / conf.), Cambridge, IAH, p. 118-154.

[48] Allison, G. B., Barnes, C. J., Hughes, M. W., Leaney, F. W. (1984). The effect of climate and vegetation on oxygen-18 and deuterium profiles in soils. In: Isotope Hydrology 1983, Proc. Symp. IAEA, IAEASM-270/20, IAEA, Vienna, pp 105-123.

[49] Travi, Y., Gac, J. Y., Fontes, J. C., Fritz, B. (1987). Reconnaissance chimique et isotopique des eaux de pluies du Sénégal. Géodynamique 2 (1): 43 - 53.

[50] Jeuken, B. M. (2004). A hydrogeochemical study of the surficial aquifers south of Alice Springs. Honours Thesis, Flinders University of SA, 2004.

[51] Allison, G. B., Hughes, M. W. (1977). The use of natural tracers as indicators of soil-water movement in a temperate semi-arid region. J. Hydrol. 60: 157-173.
[52] Clark, I. and Fritz, P. (1997). Environmental isotopes in hydrogeology. Lewis publisher. USA. 328p.

[53] Egboka, B. C. E., Cherry, J. A., Farvolden, R. N., Frind, E. O. (1983). Migration of contaminants in groundwater at a landfill a case study. 3. Tritium as an indicator of dispersion and recharge. J Hydrol 63: 51-80.

[54] Robertson, W. D., Cherry, J. A. (1989). Tritium as an indicator of recharge and dispersion in a groundwater system in central Ontario. Water Resour Res 25: 1097-1109.

[55] Buckley, R. L., Rabun, III R. L., and Heath, M. (2016). Analysis of a Global Database Containing Tritium in Precipitation February 17, 2016 SRNL-STI-2016-00071. Served as summer intern through Savannah River Tritium Enterprise 1-29 pp.

[56] Maloszewski, P., Zuber, A. (1982). Determining the turnover time of groundwater systems with the aid of environmental tracers: 1. Models and their applicability. J. Hydrol. 57, 207231.

[57] Leduc, C., Taupin, J. D., Le Gal La Salle, C. (1996). Estimation de la recharge de la nappe phréatique du Continental terminal (Niamey. Niger) à partir des teneurs en tritium. C. R. Acad. Sci. Paris. Série IIa 323. 599-605. 